\title{
Studying the behavioral changes in schizophrenic rats induced by chronic exposure to ketamine
}

\author{
Mona El Sayed ${ }^{1}$; Samiha M. Abd El Dayem; Asmaa M. Zaazaa ${ }^{* 1}$; Hanaa H. Ahmed ${ }^{2}$ \\ ${ }^{1}$ Department of Zoology -Girl's college for Arts, Science and Education. Ain Shams University. \\ ${ }^{2}$ Department of Hormones, National Research Centre, Cairo, Egypt.
}

\begin{abstract}
Schizophrenia is a chronic and highly complex psychiatric disorder characterised by cognitive dysfunctions, negative and positive symptoms. The major challenge in schizophrenia research is lack of suitable animal models that mimic the core behavioural aspects and symptoms of this devastating psychiatric disorder. In this study, we used classical and atypical antipsychotic drugs to examine the predictive validity of ketamine-enhanced immobility in forced swim test (FST) as a possible animal model for the negative symptoms of schizophrenia. Repeated administration of a subanaesthetic dose of ketamine $(0.1 \mathrm{mg} / \mathrm{kg}$ b.wt.) for 60 days enhanced the duration of immobility in FST $24 \mathrm{~h}$ after the final injection. Suggesting that the effects of ketamine on the duration of immobility in this study was neither due to motor dysfunction nor peripheral neuromuscular blockade. Our results suggest that repeated treatment with subanaesthetic doses of ketamine enhance the duration of immobility in FST, which might be a useful animal model for the negative symptoms (particularly the depressive features) of schizophrenia.
\end{abstract}

Key words: Schizophrenia, ketamine, forced swim test, rats.

\section{Introduction}

Schizophrenia (SCZ), one of the major psychoses, affects more than $1 \%$ of the whole human population (Bhugra, 2006; Nagai et al., 2011). SCZ patients are characterized by delusions, hallucinations, disorganized speech and behavior etc. (APA, 2013). These symptoms also include social dysfunction, which additionally affects family members and burden the society. Despite the importance, there is no cure for SCZ. Many partially effective therapies exist, but none can guarantee a cure to a specific case of the disease. The mechanism of all recently available antipsychotic drugs was discovered 60 years ago (Carlsson and Lindqvist, 1963; and van Rossum, 1966), their main therapeutic effect is the blockade of dopaminergic receptors (Demeter et al., 2016).

- Corresponding author: asmaa.zaazaa@women.asu.edu.eg 
Likewise, though increased immobility in a forced swimming test following chronic exposure of N-methyl-D-aspartate (NMDA) antagonists has been considered analogous to the induction of "emotional blunting" in schizophrenia, the specificity and pertinence of this read out remains debatable (Neill et al., 2014). Though the induction of immobility by neuroleptics/D2 receptor blockade might be claimed as related to "secondary negative symptoms", it is hard to differentiate a putative impact of drugs on motor behavior, depressed mood and other factors from any putative induction of "emotional blunting". Nonetheless, the enhanced immobility associated with chronic exposure to 1-phenylcyclohexylpiperidine (PCP) was reversed by DCycloserine (and sub-chronic clozapine, but not haloperidol) suggesting that further study is warranted (Murai et al., 2007; Turgeon et al., 2007).

Ketamine (Ket) is a dissociative anaesthetic with pharmacological effects similar to PCP, affecting glutamatergic activity via blockade of the NMDA receptor (Ellison, 1995). Ket was found to reinstate unique individual psychoses in remitted schizophrenic patients (Lahti et al., 1995 a, b). Therefore, this substance is also used to assess positive and negative symptoms of schizophrenia in humans such as deficits in auditory and visual context dependent processing, changes in $\left[{ }^{11} \mathrm{C}\right]$ raclopride-specific binding, robust increases in 2-deoxyglucose (2-DG) uptake in limbic cortical regions, hippocampal formation, nucleus accumbens, and basolateral amygdala, increased cerebral blood flow in anterior cingulate cortex and reduced cerebral blood flow in the hippocampus and primary visual cortex, and visual perceptional alterations (Umbricht et al., 2000; Duncan et al., 2001) and animals (Miyamoto et al., 2001). It was demonstrated that repeated injection of sub anaesthetic doses of the substance induces subtle changes in cellular distribution of calcium sensor proteins, which in part resemble those recently described in postmortem brains of human schizophrenics (Bernstein et al., 2003).

The aim of the present work was to evaluate the effect of long exposure of ketamine on the behavior of rats. This goal could be a chivied through assessment of forced swimming test of schizophrenic rats.

\section{Materials and Methods}

\section{Chemicals and drugs}

Ketamine was obtained from Trittau, Germany. All other reagents, solvents and chemicals used for analysis met the quality criteria in accordance with international standards.

\section{Biological assay}

\section{Animals and treatment}

All the experiment involving animals and tissue samples were conducted in accordance with the principles and guidelines for the care and use of laboratory animals of the National Institute of Health (NIH) (USA). This study was approved by the Ethical Committee for animal experimentation, National Research Centre, Egypt. 
Twenty adult male albino rats of Wistar strain weighing $120 \pm 10$ gm at 90 days of age were enrolled in the present study. The animals were obtained from the Animal House Colony of the National Research Centre, Cairo, Egypt. The animals were housed throughout the experiment (8 rats/cage) in polypropylene cages under specific pathogen free (SPF) conditions with controlled illumination (12 h light/12 h dark cycle), a relative humidity (30-50\%) and temperature (18-22 Co). Animals were fed with standard laboratory rat diet and water provided ad libitum. All animals received human care in compliance with the guidelines of the Ethical committee of Ain Shams University, Cairo, Egypt.

Rats were divided into two groups after 1 week of acclimation (con $(n=10)$ which received a $0.9 \%$ saline solution and Ketaminized $(n=10)$ ) were received a daily orally administration of ketamine $(0.1 \mathrm{mg} / \mathrm{kg}$ b.wt.) for 60 days to establish the animal model of schizophrenia according to (Fraga et al., 2011) as the SCZ group.

\section{Behavioral assessment}

\section{Forced swim test (FST)}

Schizophrania-like behavior was assessed using the forced swim test. Each rat was placed individually in a transparent plastic cylinder (diameter: $40 \mathrm{~cm}$, height: $60 \mathrm{~cm}$ ) filled with water to a height of $40 \mathrm{~cm}$. Rats were forced to swim for $5 \mathrm{~min}$, the duration of immobility was recorded during the last $3 \mathrm{~min}$. Stopping, struggling and floating on the surface of water indicated immobility. The test was video-recorded and analyzed later. Water was renewed each time and temperature was kept at $26{ }^{\circ} \mathrm{C}$ (Desikan et al., 2014).

\section{Statistical analysis}

The results of the present study were expressed as mean \pm S.E. of the mean. Statistical Package for the Social Sciences (SPSS) program, version 19.0 was used to compare the significance between every two groups. Difference was considered significant when $\mathrm{P}<0.05$. Percentage the difference representing the percent of variation with respect to the corresponding control group was calculated according to the following formula:

$\%$ Difference $=[($ Treated value - control value $) /$ control value $] \times 100$

\section{Results}

\section{Behavioral assessment}

\section{Forced swimming test}

In the FST, rats were forced to swim in a restricted space from which they could not escape, and as they were induced to a characteristic behavior of immobility. This behavior reflects a state of despair which can be reduced by several agents that are therapeutically effective in human schizophrenia. The current results of the FST revealed that the orally administration of ketamine in adult male rats for 60 days leads to significant increase $(\mathrm{P}<0.05)$ in the immobility time for each administered group compared with the immobility time for its corresponding group at zero time (Table 1). The SCZ group (after 60 days) recorded 182.32s vs 55.00s for its corresponding 
group at zero time representing a percent of difference $220.30 \%$ increase in the immobility time corresponding group at zero time.

Table (1) Effect of ketamine on immobility duration in forced swim test in male rats. Data are represented as mean \pm S.E.M $(n=10)$.

\begin{tabular}{||c|c|c||}
\hline \multirow{2}{*}{ Groups } & \multicolumn{2}{|c|}{ Immobility time (seconds) } \\
\cline { 2 - 3 } & Zero time & $\begin{array}{c}\text { After 60 days of Ketamin } \\
\text { administration }\end{array}$ \\
\hline Con group & $57.00 \pm 7.10$ & $56.92 \pm 5.13$ \\
\hline SCS group & $55.00 \pm 5.26$ & $182.32 \pm 7.15^{\mathrm{a}}$ \\
& & $\mathrm{a}(220.30 \%)$ \\
\hline
\end{tabular}

a: Significant change at $\mathrm{P}<0.05$ in comparison with Con group.

\section{Discussion}

Schizophrenia is a chronic, life-long and debilitating disorder which is triggered in a complex, heterogeneous and multifactorial fashion by a diverse palette of genetic, epigenetic, developmental and environmental risk factors (Millan, 2013). The symptoms of schizophrenia are clustered into three categories: cognitive dysfunctions positive and negative symptoms (Crismon et al., 2008; Jones et al., 2011).

Increasing evidence supports the dysfunction of the glutamatergic system as a primary pathophysiological change in schizophrenia (Coyle et al., 2003). Pharmacological evidence for the role of glutamate in schizophrenia centers on findings that blockade of the NMDA receptor channel complex by non-competitive antagonists induce symptoms commonly seen in schizophrenia and produce psychotic symptoms in normal volunteers that are accompanied by progressive withdrawal and poverty of speech, akin to the negative symptoms of schizophrenia even at low doses. Non-competitive NMDA receptor antagonists, such as ketamine or PCP rekindle or exacerbate psychotic symptoms in both stabilised chronic and acute schizophrenic patients (Malhotra et al., 1997).

Repeated administration of subanaesthetic doses of ketamine enhanced the duration of immobility of rats in the FST paradigm; the effect persisted for 21 days after withdrawal of the drug (Chatterjee et al., 2011). Depression is one of the major negative symptoms of schizophrenia (Barnes et al., 1989) and forced swim-induced immobility in rodent is an acceptable animal model of depression (Porsolt et al., 1978) that reflects a state of 'despair' in the rat and reduction in the immobility time serves as a specific and selective index of antidepressant activity (Page et al., 1999; Weiner et al., 2003). 
In the FST, rats are forced to swim in a restricted space from which they cannot escape and are induced to a characteristic behavior of immobility. This behavior reflects a state of despair which can be reduced by several agents that are therapeutically effective in human depression (Willner, 1984). Moreover, El-Shamy et al. (2010) suggested that the increased immobility time in the FST may represent a condition similar to human depression. The results of the FST in the present study revealed significant increase in the immobility time of the group of rats administered ketamine for 60 days as compared to its corresponding group at zero time (non ketaminized rats). This finding is in agreement with El-Shamy et al. (2010)

Therefore, an increase in immobility time in the FST following repeated administration of a subanaesthetic dose of ketamine indicates an increase in the state of behavioral despair that connotes depression, which is an important characteristic feature of the negative symptoms of schizophrenia (Crismon et al., 2008).

The effect of ketamine on the immobility time was due to motor dysfunction, such as decrease locomotor activity or ataxia. Repeated administration of ketamine had an effect on motor coordination in the animals suggesting that the enhancement of the immobility time by ketamine might be elicited via central mechanisms, not by peripheral neuromuscular blockade (Chindo et al., 2003).

Moreover, studies appointed that acute and sub chronic ketamine administration induces negative, positive and cognitive symptoms of schizophrenia (Becker and Grecksch, 2004). This data showed that the administration of the acute doses of ketamine provoked an increase of the lipid peroxidation, verified in hippocampus and striatum of the control group. In fact, ketamine administration increases metabolism in hippocampus and provoke the energetic activation in this structure (Duncan et al., 1998). It has been suggested that blockade of NMDA receptors can modulate neuronal projections and alter the activation of hippocampus resulting in behavioral abnormalities (Csernansky et al., 2005).

\section{Conclusion}

Here, we reported on face validity (changed social behavior) in a potential animal model in schizophrenia research. To find out whether predictive validity is also given, social behavior in subchronically ketamine-treated animals.

\section{References}

American, Psychiatric, Association, Diagnostic and Statistical Manual of Mental Disorders (DSM-5®) (2013).

Barnes TRE. ; Curson DA.; Liddle PF. and Patel M.(1989): The nature and prevalence of depression in chronic schizophrenic in patients. Br. J. Psychiatry. (154):486-91. 
Becker A. and Grecksch G. (2004): Ketamine-induced changes in rat behaviour: a possible animal model of schizophrenia. Test of predictive validity. Progress in Neuro-Psychopharmacol. \& Biological Psychiatry (28):1267-1277.

Bernstein, H.-G.; Becker, A.; Keilhoff, G.; Spilker, C.; Gorczyca, A.; Braunewell, K.-H. and Grecksch, G. (2003): Brain region-specific changes in the expression of calcium sensor proteins after repeated applications of ketamine to rats. Neurosci. Lett. (339): 95-98.

Bhugra D. (2006): Severe mental illness across cultures, Acta Psychiatr. Scand. Suppl. 429:1723.

Carlsson A.; Lindqvist M. (1963): Effect of chlorpromazine or haloperidol on formation of 3methoxytyramine and normetanephrine in mouse brain, Acta Pharmacol. Toxicol. (20) :140144.

Chatterjee N.; Sinha D.; Lemma-Dechassa $\quad$ M.; Tan $\quad$ S.; Shogren-Knaak MA. and Bartholomew B. (2011): Histone H3 tail acetylation modulates ATP-dependent remodeling through multiple mechanisms. Nucleic Acids Res39(19):8378-8391.

Chindo BA.; Amos S.; Odutola AA.; Vongtau HO.; Abbah J. and Wambebe C, et al.(2003) :Central nervous system activity of the methanol extract of Ficus platyphylla stem bark. $J$. Ethnopharmacol. (85):131-7.

Coyle JT.; Tsai G. and Goff D. Converging evidence of NMDA receptor hypofunction in the pathophysiology of schizophrenia (2003): Ann. N.Y. Acad. Sci. (1003):318-327.

Crismon ML.; Argo TR. and Buckley PF. (2008): Schizophrenia. In: Dipiro JT, Talbert RL, Yee GC, Matzke GR, Wells BG, Posey ML, editors. Pharmacotherapy: a pathophysiologic approach. 7th edition. McGraw-Hill Co. Inc. p. 1099-1122.

Csernansky JG.; Martin M.; Shah R.; Bertchume A.; Colvin J. and Dong H. (2005): Cholinesterase inhibitors ameliorate behavioral deficts induced by MK-801 in mice. Neuropsychopharmacol. (30):2135-2143.

Demeter K.; Török B.; Fodor A.; Varga J.; Ferenczi S.; Kovács K.J.; Eszik L.; Szegedi, V. and Zelena, D.(2016): Possible contribution of epigenetic changes in the development of schizophrenia-like behavior in vasopressin-deficient Brattleboro rats. Behavioural Brain Res. (300) :123-134.

Desikan A.; Wills D. and Ehlers C. (2014): Ontogeny and adolescent alcohol exposure in Wistar rats: open field conflict, light/dark box and forced swim test. Pharmacol. Biochem. Behav., (122):279-285. 
Duncan GE.; Leipzig JN.; Mailman RB. and Lieberman JA. (1998): Differential effects of clozapine and haloperidol on ketamine-induced brain metabolic activation. Brain Res. (812):6575.

Duncan E.J.; Madonick S.H.; Parwani A.; Angrist B.; Rajan R.; Chakravorty S.; Efferen T.R.; Szilagyi S.; Stephanides M.; Chappell P.B.; Gonzenbach S.; Ko G.N. and Rotrosen J.P. (2001): Clinical and sensorimotor gating effects of ketamine in normals. Neuropsychopharmacol. (25): 72-83.

Ellison G. (1995): The N-methyl-d-aspartate antagonists phencyclidine, ketamine and dizocilpine as both behavioral and anatomical models of the dementias. Brain Res. Brain Res. Rev. 20, 250-267.

El-Shamy K.A.I.; Noor Eldeen A.F.H.; Khadrawy Y.A.; Helmy A.S. and Hosny E.N.(2010): The antidepressant effect of curcumin in an animal model of depression. Egy. Med. J. Nat. Res. Centre., 9(1): 49-57.

Fraga, D.B.; Deroza, P.F.; Ghedim, P.V.; Steckert, A.V.; De Luca, D.D.; Silverio, A.; Cipriano, A.L.; Leffa, D.D.; Borges, G.D.; Quevedo, J.; Pinho, R.A.; Andrade, V.M.; Dal-Pizzol, F. and Zugno, A.I. (2011): Prenatal exposure to cigarette smoke causes persistent changes in the oxidative balance and in DNA structural integrity in rats submitted to the animal model of schizophrenia. Journal of Psychiatric Research, 45, 1497-1503.

Jones CA.; Watson DJG. and Fone KCF. (2011): Animal models of schizophrenia. Br. J. Pharmacol. (164):1162-1194.

Lahti A.C.; Holcomb H.H.; Medoff D.R. and Tamminga C.A. (1995a): Ketamine activates psychosis and alters limbic blood flow in schizophrenia. Neuro.Report. (6): 869-872.

Lahti A.C.; Koffel B.; LaPorte D. and Tamminga C.A. (1995b): Subanesthetic doses of ketamine stimulate psychosis in schizophrenia. Neuropsychopharmacol. (13): 9- 19.

Malhotra AK.; Pinals DA.; Adler CM.; Elman I.; Clifton A.; Pickar D. and Breier A (1997): Ketamine-induced exacerbation of psychotic symptoms and cognitive impairment in neuroleptic-free schizophrenics. Neuropsychopharmacol. (17):141-150.

Millan M.J. and Bales K.L. (2013): Towards improved animal models for evaluating social cognition and its disruption in schizophrenia: the CNTRICS initiative. Neurosci. Biobehav. Rev. (37): 2166-2180.

Miyamoto S.; Mailman R.B.; Lieberman J.A. and Duncan, G.E. (2001): Blunted brain metabolic response to ketamine in mice lacking $\mathrm{D}(1 \mathrm{~A})$ dopamine receptors. Brain Res. (894): $167-180$. 
Murai R.; Noda Y.; Matsui K.; Kamei H.; Mouri A.; Matsuba K.; Nitta A.; Furukawa H. and Nabeshima T. (2007): Hypofonctional glutamatergic neurotransmission in the prefrontal cortexis involved in the emotional deficit induced by repeated treatment with phencyclidine in mice: implications for abnormalities of glutamate release and NMDA-Ca MKII signaling. Behav. Brain Res. (180):152-160.

Nagai T.; Ibi D. and Yamada K. (2011): Animal model for schizophrenia that reflects geneenvironment interactions, Biol. Pharm. Bull. (34): 1364-1368.

Neill J.C.; Harte M.K.; Haddad P.M.; Lydall E.S. and Dwyer D.M. (2014): Acute and chronic effects of NMDA receptor antagonists in rodents, relevance to negative symptoms of schizophrenia: a translational link to humans. Eur. Neuropsychopharmacol. (24): 822-835.

Page ME.; Detke MJ.; Kirby ADLG. and Lucki I. (1999): Serotonergic mediation of the effects of fluoxetine, but not desipramine, in the rat forced swimming test. Psychopharmaco. (147):62-67.

Porsolt RD.; Anton G.; Blavet N. and Jalfre M. (1978): Behavioural despair in rats: a new model sensitive to antidepressant treatments. Eur. J. Pharmacol. (47):379-391.

Turgeon S.M.; Lin T. and Subramanian M. (2007): Sub chronic phencyclidine exposure potentiates the behavioral and c-Fosresponse to stress fulstimuli in rats. Pharmacol. Biochem. Behav. (88): 73-81.

Umbricht D.; Schmid L.; Koller R.; Vollenweider F.X.; Hell D. and Javitt D.C. (2000): Ketamine-induced deficits in auditory and visual contextdependent processing in healthy volunteers: implications for models of cognitive deficits in schizophrenia. Arch. Gen. Psychiatry (57): 1139-1147.

Van Rossum J.M. (1966) :The significance of dopamine-receptor blockade for the mechanism of action of neuroleptic drugs, Arch. Int. Pharmacodyn. Ther. (160): 492-494.

Weiner I.; Schiller D.; Gaisler-Salomon I.; Green A. and Joel D.(2003): A comparison of drug effects in latent inhibition and the forced swim test differentiates between the typical antipsychotic haloperidol, the atypical antipsychotics clozapine and olanzapine, and the antidepressants imipramine and paroxetine. Behav. Pharmacol. (14): 215-522.

Willner p.(1984): The validity of animal models of depression.psychopharmacol.(Berl),72(1): 915. 


\section{الملخص باللغة العربية}

دراسة التغيرات السلوكية لمرض انفصام الشخصية فى نموذج جرذان التجارب الناجم عن التعرض المزمن للاكيتامين

المستخلص

انفصام الثخصية هو اضطراب نفسي مزمن ومعقد للغاية يتميز بخلل وظيفي إدراكي وأعراض سلبية وإيجابية. التحدي الرئيسي في أبحاث الفصام هو عدم وجود نماذج حيوانية مناسبة تحاكي الجوانب السلوكية الأساسية وأعراض هذا الاضطراب النفسي المدمر. في هذه الاراسة ، استخدمنا الأدوية المضادة للأهان الكلاسيكية وغير التقليدية لاراسة الصلاحية التتبؤية لعدم الحركة المعززة بالكيتامين في اختبار السباحة القسري (FST) كنموذج حيواني محتمل للأعراض السلبية لمرض انفصام الشخصية. تناولت الإدارة المتكررة لجرعة تحت جمالية من الكيتامين (1 . ملغم / كغم من وزن الجسم) لمدة ، 7 يومًا مدة عدم الحركة في FST 24 ساعة بعد الحقن النهائي. مما يوحي بأن آثار الكيتامين على مدة الجمود في هذه الدراسة لم يكن بسبب الخلل الحركي ولا الحصار العصبي العضلي المحيطي. تثبر النتائج التي توصلنا إليها إلى أن العلاج المتكرر مع جرعات الكيتامين دون التجميلية يعزز مدة الجمود في FST ، والتي قد تكون نموذجًا حيوانيًا مفيدًا للأعراض السلبية (خاصة الخصائص الاكتئابية) لمرض الفصام. 